\section{Ireland appoints group to draft science white paper}

\begin{abstract}
Munich. The government of the Irish Republic last week announced the members of an independent committee that will carry out the first review of its science and technology policy for more than 30 years. The 18 -strong committee, known as the Science, Technology and Innovation Council, is being asked to prepare a draft white paper (policy document) by the end of this year.

The Minister for Commerce and Technology, Seamus Brennan, responded to complaints about the government's handling of research funds last September by announcing an investigation into Ireland's science policy (see Nature 365, 197; 1994) But setting up the committee to carry

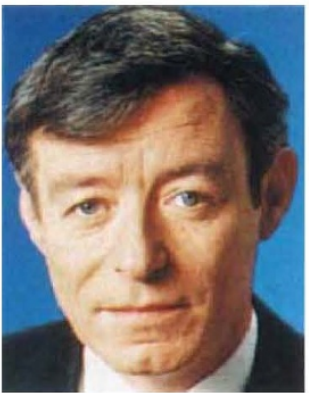
Brennan: listening to advice.
\end{abstract} this out has taken

longer than expected, chiefly because of disagreement about its composition.

Despite the delay, the Irish Research Scientists Association (IRSA), the main lobby group for science, has welcomed the announcement. David Fegan, a physics lecturer who acts as the group's secretary, says that the make-up of the committee, which includes six academics, nine industrialists and three civil servants and which is chaired by Dan Tierney, chairman of the Cross Chemical Group, is "better than we'd hoped", as at one point it was uncertain whether the group would include any academics at all.

"The establishment of the committee is a very positive step," he adds, "and we hope that the [draft] white paper will eventually become national policy." If nothing else, he says, it brings the government into direct contact with scientists.

But the problems that precipitated last year's strife are continuing. Forbairt, the newly created agency that administers research grants, has still not been told what its budget will be for this year. It does not yet know if there will be any money at all for new research projects, although spokesman Martin Lyes says he is "hopeful of getting around I£750,000".

Meanwhile Forbairt is honouring its commitments to existing projects, for which it will provide about $\mathrm{I} £ 800,000$ in 1994 . But it is not risking a second public outcry by announcing a call for new proposals, as it did last year, before funding is secure.

Michael Fahy, from the government's Office of Science and Technology, says that a decision about the Forbairt budget should be taken within a week. The delay, he says, has been caused by uncertainties over the use of 'structural funds' from the European Commission, which may influence priorities for the office's total budget of I£18.6 million (US\$1 million)

Many scientists are angry about the continued absence of grant money, and the general lack of information about what is going on. "We are treated worse than children", says Alan Baird, a lecturer in pharmacology at University College, Dublin, who last month lost a potential postgraduate student to the United Kingdom because he could not offer a definite prospect of a grant.

Meanwhile in response to a threat last autumn from the UK-based Wellcome Trust to withdraw all its research funding from the Republic of Ireland, the government in Dublin has announced an increase of almost 30 per cent in its health research budget.

The government has also said that refunds of valued added tax (VAT) might be allowed on certain items of medical research equipment at the discretion of the finance minister. But Brian Harvey, professor of physiology at University College, Cork, himself a Wellcome grant-holder, says that the concessions may be too small to make a difference.

In a letter to Bertie Ahern, Ireland's finance minister, last November, Bridget Ogilvie, the director of the Wellcome Trust, said that the trust was unhappy both about the fact that it spends twice as much on Irish medical research (around I£5 million) as the government, and that it has to pay VAT at 21 per cent on any research equipment that it buys, using money that would otherwise go to research.

Last year, the trust paid $\mathrm{I} £ 100,000$ in VAT. As most items of research equipment cost less than If20,000 individually, the new ruling is likely to make little difference this year. Ireland is the only Organization for Economic Cooperation \& Development country to charge VAT on research equipment.

Ahern has so far declined a request to discuss the matter directly with Ogilvie. Nor has he replied to a letter from Wellcome grant-holders in Ireland, sent on 18 January, requesting a meeting to discuss their call for "a realistic response in terms of overall funding policy" to halt the Wellcome threat.

A spokeswoman for Wellcome says that the trust is looking at all options to solve its problems with funding in Ireland, and does not see withdrawal as the only possible course of action. "Our major concern is that Ireland should develop a science policy," she says, "something Wellcome hopes will emerge out of the debate." Alison Abbott

\section{Parliament seeks further changes in EU Framework}

Paris. The next five-year Framework research programme of the European Union (EU) inched closer to approval last week, when the European Parliament adopted it at a second reading. Under the new procedures of the Maastricht agreement, final approval will require discussion with the Council of Ministers of the parliament's amendments, and agreement on a single text in a 'conciliation committee'

In December the council of research ministers broke the deadlock over funding of the Fourth Framework programme, scheduled to run from 1994 to 1998 , by agreeing to a budget of ECU12 billion (US\$13.6 billion), and a reserve of ECU1 billion. But parliament has now demanded an extra ECU400 million, and also sought guarantees that the agreed reserve will actually materialize.

In particular, the parliament wants to use the extra ECU400 million to increase support for international cooperation and technology transfer, and to juggle the distribution of the budget so as to spend more on socioeconomic research and telematics.

The parliament also wants to reduce the rate at which the council's plans to make the EU's four joint research centres (JRC) more competitive are introduced.

Greece, the current president of the council, is reported to have said that council will probably agree with parliament on these issues. More contentious is likely to be the parliament's demand for access to all information produced by the committees that oversee research programmes. These are made up of national civil servants and commission officials, and meet in secret.

Whatever the outcome, Claude Desama, the president of the parliament's energy, research and technology committee, says that this first experience of the codecision procedures of the Maastricht agreement shows that they need to be changed when the treaty comes up for review in 1996.

Now member states must agree unanimously on a common position, which inevitably reflects the views of the most extreme member state, and leaves little room for negotiations with parliament.

Desama also says that council has not yet entered into the spirit of the codecisionprocedure. For example, he says it has refused to try to avert problems by negotiating with the parliament informally.

In a communique, the parliament says that it is "extremely worried, and somewhat astonished" that the council has continued to take decisions "unilaterally" on such matters as the future of the JRCs, and the scheduling of instalments of the Framework budget.
Declan Butler 